\title{
Current Practice and Future Perspectives for Livestock Production and Industrial Ecology
}

\author{
Ricardo F.M. Teixeira * (1) and Tiago Domingos \\ MARETEC-Marine, Environment and Technology Centre, LARSyS, Instituto Superior Técnico, \\ Universidade de Lisboa, 1049-001 Lisboa, Portugal \\ * Correspondence: ricardo.teixeira@tecnico.ulisboa.pt; Tel.: +351-21-841-94-38
}

Received: 30 July 2019; Accepted: 1 August 2019; Published: 4 August 2019

check for updates

The year 2016 marked the 10-year anniversary of the publication of the "Livestock's Long Shadow" FAO report [1]. This landmark report influenced scientific and public perceptions of the role of livestock as a driver of environmental impacts—-for example, high greenhouse gas emissions (GHG) or threats to biodiversity. The report pinpointed livestock production as producing $8-18 \%$ of all global GHG emissions. Meat, and particularly beef, is the food product responsible for the highest emissions $[2,3]$. Reducing the global effects of animal production requires two complementary and non-exclusive strategies: demand-side change and supply-side optimization. Demand-side changes, such as a change in consumer preferences towards plant-based diets, or active discouragement of meat consumption, which would probably require major policy and economic instruments, given the current importance of the animal sector in most countries (the animal production sector is globally worth $1.4 \mathrm{T€}$ ). Global per capita consumption of meat grew from $38.9 \mathrm{~kg}$ to $42.2 \mathrm{~kg}$ between 2005 and 2011, mostly due to increased demand in developing countries. The average annual increase in global meat demand is estimated as $1.3 \%$ until 2050 [4], in spite of diet changes in developed countries. Meat is not going away any time soon.

Supply-side changes have been the focus of most research and are also the focus of the papers included in this Special Issue "Livestock Production and Industrial Ecology". As originally intended, this set of papers provides an updated look at the role of intensive and extensive animal production systems in sustainability, which can expand and improve on the findings of "Livestock's Long Shadow". Authors analyzed multiple animal production systems through the lens of industrial ecology and its quantitative tools. The analytical tools applied in these papers primarily used standard industrial ecology tools such as life cycle assessment (LCA), both attributional and consequential, and material and energy flow analysis. However, those tools were complemented with innovative features such as the application of inverse approaches for calibrating process-based models, the application of optimization algorithms, linear programming, as well as data mining. This plethora of tools is demonstrative of an increasingly multi-disciplinary effort to tackle the effects of animal production and reducing its environmental burden.

Multiple papers focused on particular farm systems. Morais et al. [5] applied an inverse approach to calibrate the process-based Rothamsted carbon model (RothC) for estimating soil carbon dynamics in sown biodiverse permanent pastures rich in legumes (SBP) [6,7]. These grass-legume pastures with up to 20 species/cultivars increase grassland productivity [7] and sustainable stocking rates [8]. Previous research had shown that SBP can accelerate the rate of accumulation of soil organic matter [9] and, thus, sequester large quantities of carbon in soils [10], which can temporarily offset the carbon emissions from meat production. To further characterize and better understand these effects, the authors managed to calibrate RothC using data for multiple farms and years and estimate critical parameters that so far have not been measured in SBP, such as root to shoot ratios and carbon mineralization rates. They used the model after calibration for a dataset consisting only of soil organic carbon (SOC) measurements 
and estimated the yield and stocking rates involved, showing that this approach can be effective in suppressing data gaps.

Using the new knowledge found in this first paper [5], Teixeira et al. [11] proposed a new carbon and nitrogen balance model for both semi-natural pastures and SBP, entitled "BalSim". This innovative model proposes a mass-balance approach to calculating plot or farm-level GHG balances of pastures. The authors showed that while beef production in semi-natural pastures produces $0.8 \mathrm{t} \mathrm{CO}_{2} \mathrm{e} / \mathrm{ha} \cdot \mathrm{yr}$, the balance for production in SBP is, on average, $-2.6 \mathrm{t} \mathrm{CO}_{2} \mathrm{e} / \mathrm{ha} \cdot \mathrm{yr}$ due to carbon sequestration. Taking into account only non- $\mathrm{CO} 2$ emissions, the two pasture systems are responsible for approximately the same emissions (16.3 kg and $17.0 \mathrm{CO}_{2} \mathrm{e} / \mathrm{kg}$ live weight.yr, respectively). The authors also ran several scenarios for pasture yield and grazing intensity, and found that the lowest emissions, highest carbon accumulation in soils and lowest nitrogen loss are obtained when the grazing level is adapted to the yield in order to maximize grass growth and intake.

This paper enabled the calculation of a direct, on-farm GHG balance. A second paper by Morais et al. [12] expanded the scope of this analysis and introduced the entire beef production supply chain. The authors performed a consequential life cycle assessment (LCA) of beef production in SBP. This was the first LCA of this innovative pasture system. The analysis assessed the GHG emission balance of switching from a beef production system that resorted to semi-natural pastures supplemented with concentrate to a system where SBP, which are more productive, replace the concentrate. The authors showed that carbon sequestration in SBP is more than sufficient to offset the extra emissions from the production of fertilizers and seeds used in SBP. More importantly, they showed that even after SBP saturate with carbon and sequestration is negligible, the replacement of the concentrate alone avoids the emission of about $3 \mathrm{tCO}_{2} \mathrm{eq} / \mathrm{ha}$. These results, when converted to a $\mathrm{kg}$ of live weight basis, mean that SBP can avoid $25 \%$ emissions from beef production.

Milk production systems were the focus of another paper by Morais et al. [13]. The authors calculated the carbon footprint of milk produced in 25 pasture-based farms in the Azores islands. Animal systems in Atlantic insular ecosystems are critically understudied in the literature but are of critical importance locally and can possess several advantages such as the potential to produce grass for feed year-round. The production of each $\mathrm{kg}$ of milk causes the emission of $0.83 \mathrm{~kg} \mathrm{CO}_{2} \mathrm{e}$, which is approximately $32 \%$ lower than the average emissions of other benchmark production systems. The authors ascribe these results to the fact that the farms have high milk yields that dilute the basal emissions from cows, but caution against the intensification of production as the key to reducing emissions per unit of product. Further increases in yield could entail more-than-proportional increases in concentrate feed use and decrease the overall carbon eco-efficiency of the system.

Assessing the environmental effects of animal production requires the full quantification of ecosystem services. Recent years have seen an increase in the publication of ecosystem services and biodiversity impact assessment models for inclusion in standard industrial ecology tools such as LCA studies, but so far these have hardly been implemented in actual analyses. Teixeira et al. [14], in regard to this issue, compares available models using the consequential LCA analysis of SBP proposed by Morais et al. [12] as a case study. This analysis showed that each hectare of SBP installed avoids the occupation of 0.5 hectares per year of cropland for feed ingredient production. The authors quantified the decrease in ecosystem degradation due to saving land. They also uncovered important information for the future development of similar models, as they found that regionalizing life cycle inventories for $70 \%$ of land use flows only changes results by $15 \%$, suggesting limited spatial differentiation between country-level characterization factors. They also found substantial redundancies between ecosystem services impact assessment models, and even models for biodiversity loss. They suggest that future models focus on increasing the number of land classes, which so far are very limited and considerably diminish the reliability of the LCA studies that could benefit from applying the models.

The papers mentioned previously studied plot-level or farm-level integrated production systems. Other papers focused on entire sectors. Segura et al. [15] devised a new optimization model to reduce nitrogen excretion in the Spanish pig sector. They produced a linear programming model that uses 
information on dietary requirements for pigs (metabolizable and net energy, crude protein, etc.), as well as information about available stocks and prices of raw materials. The model determines the best combinations that minimize feed costs and calculates nitrogen excretion for optimum diets. This model produced better estimates of nitrogen emissions that were previously available, enabling scenario assessments. The approach can also be emulated for other types of animals and countries.

Huang et al. [16] also tackled pig production, in this case in China. Their goal was to perform a multi-objective (economic and environmental) optimization of China's swine farming industry. The authors implemented an innovative and multi-layered data mining approach, involving clustering and classification of performance groups based on economic and environmental characteristics of the farmers. The paper shows that environmental regulation intensity is associated with good overall performance of the farms. However, it is also the case that in the absence of regulation, farm profit was negatively correlated with increased pollution. The authors conclude that regulation intensity can help reduce emissions, but, even in its absence, pollution control can be beneficial for the profit of the farm. The results are region-specific, i.e., clusters of farms have different levels of economic and environmental performance depending on their location in the country.

Finally, the paper published by Harchaoui et al. [17] had an even broader scope, as it tackled the entire agricultural sector in France. The study focused on the important issue of the double role of agriculture as a food and energy-producing activity and asked whether French agriculture could become energy-neutral. The authors found that at the moment French agriculture is energy deficient, i.e., it requires more external energy inputs than it can produce within the sector. The study concludes that energy neutrality would require ending the production of feed from cropland, as well as very high energy recovery from crop residues and manure. The authors also make an important link to demand-side policies as reduced food waste and/or reduced per capita caloric intake could potentially at least reduce the external energy demand, as France currently produces food equivalent to $3480 \mathrm{kcal}$ per person, while the recommended caloric intake is $2200 \mathrm{kcal}$. This stresses the importance of combining approaches to design better strategies for livestock production optimization. Supply and demand-side improvements are not necessarily conflicting and should both be a part of the integrated transformations of food systems.

The papers published in this Special Issue revealed also important messages towards sustainable animal production. They collectively demonstrate the key importance of optimizing animal feed. For concentrates, it is essential to optimize feed formulations and use co-products to the fullest, to avoid dedicated crop production and ensure optimum energy reuse, in line with circular economy principles. Pasture-based production should be optimized for ruminants as a potential source of ecosystem services, primarily through cropland sparing and carbon sequestration. Throughout these analyses, economic performance should always be explicitly taken into consideration when performing emissions reductions.

An additional unexplored topic in this set of papers, to which special attention should be paid, is the social component of animal production, namely labor issues. Enteric methane emissions are one of the main sources of GHG emissions from livestock production, and their optimization must also be increasingly addressed in future studies. In spite of the examples in the Special Issue considering carbon sequestration effects from livestock production in grasslands, most LCA-based analyses in the literature remain focused on negative effects such as emissions. It is restrictive to assume that optimizing livestock production means only reducing emissions, as animals can also generate environmental amenities. The impacts of livestock production are highly variable depending on the region of production and feed regime (extensive or intensive) [18]. Pasture-based systems have a potentially beneficial role [19] as they contribute to faster and more balanced nutrient recycling in ecosystems [20], use marginal land unsuitable for crops [21], and legume-based pastures are a biological source of nitrogen for soils and protein for livestock [22]. All those effects can be explored through the lens of industrial ecology and should additionally be the focus of follow-up studies. 
Author Contributions: The writing and original draft preparation was led by R.T.; both authors contributed to the conceptualization, review and editing of the paper.

Acknowledgments: This work was supported by FCT/MCTES (PIDDAC) through project UID/EEA/50009/2019 and by project Animal-Future-Steering Animal Production Systems Towards Sustainable Future, funded by Fundação para a Ciência e Tecnologia (SusAn/0001/2016). R. Teixeira was supported by grant SFRH/BPD/111730/2015 from Fundação para a Ciência e Tecnologia.

Conflicts of Interest: The authors declare no conflict of interest. The funders had no role in the design of the study, in the collection, analyses, or interpretation of data; in the writing of the manuscript, or in the decision to publish the results.

\section{References}

1. Steinfeld, H.; Gerber, P.; Wassenaar, T.D.; Castel, V.; de Haan, C. Livestock's Long Shadow: Environmental Issues and Options; Food and Agriculture Organization of the United Nations: Rome, Italy, 2006; ISBN 9789251055717.

2. Tilman, D.; Clark, M. Global diets link environmental sustainability and human health. Nature 2014, 515, 518-522. [CrossRef]

3. Poore, J.; Nemecek, T. Reducing food's environmental impacts through producers and consumers. Science 2018, 360, 987-992. [CrossRef]

4. Alexandratos, N.; Bruinsma, J. (Eds.) World Agriculture Towards 2030/2050; ESA Working Paper No. 12-03; Food and Agriculture Organization of the United Nations: Rome, Italy, 2012.

5. Morais, T.; Teixeira, R.F.M.; Rodrigues, N.G.; Domingos, T. Characterizing livestock production in Portuguese sown rainfed grasslands: Applying the inverse approach to a process-based model. Sustainability 2018, 10, 4437. [CrossRef]

6. Proença, V.; Aguiar, C.; Domingos, T. Highly productive sown biodiverse pastures with low invasion risk. Proc. Natl. Acad. Sci. USA 2015, 112, E1695. [CrossRef] [PubMed]

7. Teixeira, R.F.M.; Proença, V.; Crespo, D.; Valada, T.; Domingos, T. A conceptual framework for the analysis of engineered biodiverse pastures. Ecol. Eng. 2015, 77, 85-97. [CrossRef]

8. Teixeira, R.F.M. Sustainable Land Uses and Carbon Sequestration: The Case of Sown Biodiverse Permanent Pastures Rich in Legumes. Ph.D. Thesis, Instituto Superior Técnico, Lisbon, Portugal, 2010.

9. Teixeira, R.F.M.; Domingos, T.; Costa, A.P.S.V.; Oliveira, R.; Farropas, L.; Calouro, F.; Barradas, A.M.; Carneiro, J.P.B.G. Soil organic matter dynamics in Portuguese natural and sown rainfed grasslands. Ecol. Model. 2011, 222, 993-1001. [CrossRef]

10. Teixeira, R.F.M.; Domingos, T.; Canaveira, P.; Avelar, T.; Basch, G.; Belo, C.C.; Calouro, F.; Crespo, D.; Ferreira, V.G.; Martins, C. Carbon sequestration in biodiverse sown grasslands. Opt. Méditerranéennes-Sustain. Mediterr. Grassl. Their Multi-Funct. 2008, A, 123-126.

11. Teixeira, R.F.M.; Barão, L.; Morais, T.; Domingos, T. “BalSim”: A Carbon, Nitrogen and Greenhouse Gas Mass Balance Model for Pastures. Sustainability 2019, 11, 53. [CrossRef]

12. Morais, T.; Teixeira, R.F.M.; Domingos, T. The Effects on Greenhouse Gas Emissions of Ecological Intensification of Meat Production with Rainfed Sown Biodiverse Pastures. Sustainability 2018, 10, 4184. [CrossRef]

13. Morais, T.; Teixeira, R.F.M.; Rodrigues, N.G.; Domingos, T. Carbon footprint of milk from pasture-based dairy farms in Azores, Portugal. Sustainability 2018, 10, 3658. [CrossRef]

14. Teixeira, R.F.M.; Morais, T.G.; Domingos, T. A Practical Comparison of Regionalized Land Use and Biodiversity Life Cycle Impact Assessment Models Using Livestock Production as a Case Study. Sustainability 2018, 10, 4089. [CrossRef]

15. Segura, M.; Maroto, C.; Ginestar, C.; Segura, B. Optimization Models to Improve Estimations and Reduce Nitrogen Excretion from Livestock Production. Sustainability 2018, 10, 2362. [CrossRef]

16. Huang, D.; Ma, Q.; Feng, L.; Wen, X.; Li, H. Applying data mining to china's swine farming industry: A compromise perspective of economic, environmental and overall performances. Sustainability 2018, 10, 2374. [CrossRef]

17. Harchaoui, S.; Chatzimpiros, P. Can Agriculture Balance Its Energy Consumption and Continue to Produce Food? A Framework for Assessing Energy Neutrality Applied to French Agriculture. Sustainability 2018, 10, 4624. [CrossRef] 
18. Teixeira, R.F.M. Critical Appraisal of Life Cycle Impact Assessment Databases for Agri-food Materials. J. Ind. Ecol. 2015, 19, 38-50. [CrossRef]

19. Wu, G.; Fanzo, J.; Miller, D.D.; Pingali, P.; Post, M.; Steiner, J.L.; Thalacker-Mercer, A.E. Production and supply of high-quality food protein for human consumption: Sustainability, challenges, and innovations. Ann. N. Y. Acad. Sci. 2014, 1321, 1-19. [CrossRef] [PubMed]

20. Bernués, A.; Ruiz, R.; Olaizola, A.; Villalba, D.; Casasús, I. Sustainability of pasture-based livestock farming systems in the European Mediterranean context: Synergies and trade-offs. Livest. Sci. 2011, 139, 44-57. [CrossRef]

21. Shahid, S.A.; Al-Shankiti, A. Sustainable food production in marginal lands-Case of GDLA member countries. Int. Soil Water Conserv. Res. 2017, 1, 24-38. [CrossRef]

22. Foyer, C.H.; Lam, H.M.; Nguyen, H.T.; Siddique, K.H.; Varshney, R.K.; Colmer, T.D.; Cowling, W.; Bramley, H.; Mori, T.A.; Hodgson, J.M.; et al. Neglecting legumes has compromised human health and sustainable food production. Nat. Plants 2016, 2, 16112. [CrossRef] [PubMed]

(C) 2019 by the authors. Licensee MDPI, Basel, Switzerland. This article is an open access article distributed under the terms and conditions of the Creative Commons Attribution (CC BY) license (http://creativecommons.org/licenses/by/4.0/). 